\title{
African Theocracy: A Panacea to Niger Delta Youth Restiveness
}

\author{
Uche A. Dike \\ Niger Delta University, Wilberforce Island, Bayelsa State, Yenagoa, Nigeria \\ Email: ucheuad@yahoo.com \\ Received 5 August 2014; accepted 24 March 2015; published 26 March 2015 \\ Copyright (C) 2015 by author and Scientific Research Publishing Inc. \\ This work is licensed under the Creative Commons Attribution International License (CC BY). \\ http://creativecommons.org/licenses/by/4.0/ \\ (c) (i) Open Access
}

\begin{abstract}
The paper is a research work on various social problems dominant in the Niger Delta. It focuses on youth restiveness and Ogba people system of traditional rulership referred to as Ogba theocracy in this paper. Its highlights is that this form of government could be used as a means of quelling Adamic sins represented in this context as youth restiveness. It pointed out some of the causative factors to Niger Delta problems. They include economic, political, oil industry, resource control, indiscipline, gangsterism etc. as major issues to Niger Delta constraints.
\end{abstract}

\section{Keywords}

Ogba Land, Theocracy, Niger Delta, Restiveness, Resource Control, Marginalisation

\section{Introduction}

Nigerian government defined Niger Delta territory as extending above 70,000 Square km, and occupies 7.5\% of Nigerian land mass. Originally, it is made up of Rivers, Bayelsa and Delta States, but today it includes Abia, Akwa Ibom, Cross Rivers, Edo, Imo and Ondo States (Amanyie, 2006: p. xii).

Every nation on earth has its own set of problems of one kind or another. Niger Delta region is no exception. At times social problems are symptoms of dynamic social life. As head-ache is normally associated with living human skulls, so also are social problems the features of living and growing human societies. Accordingly, Niger Delta is saddled with bristling social problems one of which is youth restiveness. Here, however, the purpose is to identify some of the basic or causative factors to Niger Delta youth restiveness and try as much as possible to proffer solution to them. The factors and solutions would be discussed under the following headings: political leadership, economic situation, oil industry, misplacement of societal values and the genuine struggle. 


\section{Causative Factors to Niger Delta Youth Restiveness}

\subsection{Political Leadership}

Societal life is as natural to man as leadership is a necessary social attribute. In other words, leadership is to a society or organization what the eye is to a human person. Hence, leadership is an indispensable element of any social organization, institutions, units, departments, clubs, villages, towns, states, countries or regions. Leadership therefore is the base of the society, this also allude to the fact that economic and socio-political prosperity, peace and tranquility of a state is anchored more on leadership prowess or ability to articulate the co-operation of the subjects for these objectives. Thus, the federal government is expected among others to provide the following: ensure the security of life and properties in the Niger Delta, provide employment and avenue for youth development and resourcefulness, formulate policies, guide-lines for action and co-ordinate the execution and implementation of these policies, resolve issues and conflicts, be the dedicated custodian of the welfare of those under its jurisdiction or authority (Ordu, 2011: p. 25).

In view of these vital functions of leadership, its importance in every organized unit of human beings cannot be over-emphasized. A country or nation without efficient leadership is usually doomed to exploitation, chaos, marginalization, unemployment and a state of social disarray culminating into youth restiveness. This has been the case of Niger Delta. In the Niger Delta leadership in all spheres is in a grave pathological state. Here, our socio-economic and political underdevelopment is characterized by substantial mass illiteracy, low level of political education, tribalism and lack of national consciousness, mass poverty in the midst of natural plenty, lack of mechanization and neglect of the agricultural sector of the economy, siphoning of public funds by the elite to foreign banks, conspicuous absence of social securities (such as old age, widowhood and other social disability allowances) dysfunctional communication networks and social utilities, depressed and lean foreign exchange reserves, paralyzing bureaucracy, corruption in high and low quarters, compounded and matched by the ineptitude and selfishness of those in vital position of authority and politicians. This catalogue of the factors of underdevelopment, veritable obstacles to social progress has begun to excert its impact on the collective phyche and consciousness of the Niger Delta, hence, it is no gainsaying that these deplorable situation in the Niger Delta is partly responsible for the youth restiveness in the region which need urgent attention and corrections.

\subsection{Economic Situation}

The economic field in the Niger Delta is regarded as a jungle where to get the better of the other citizen in any deal is canonized as the only gate way to success and wealth. It is a world without ethics and decent principles. Here is the zone of official contractors, businessmen, merchants, traders, transporters and bankers who do not have the interest of the masses at heart. Money is their god and he is to be worshipped absolutely without any reserve or discretion, even if it means plunging Niger Delta into a more serious peril and chaos.

Economic leadership in the Niger Delta is still divorced from professional integrity and from the spirit of service and due consideration for the rights of others. Respect for human rights and social justice is an attitude of life unpractical to the financial and economic high priests and leaders of Niger Delta. Hitherto, our political leaders have proved themselves impotent or unwilling to curb and channel positively the unbridled and irrational man-made forces of our economy, thereby plunging the country particularly the oil rich Niger Delta region into economic woes, unemployment, mass illiteracy among others leading to spontaneous restiveness.

\subsection{Oil Industry}

Niger Delta is dangerously poised on one single commodity-mineral oil because inadequate attention has been given to other natural resources such as cocoa, oil palm, animal etc. our projected industrial revolution appears far-fetched because we are still interested more in importing foreign products than in making our own. Moreover, our business men believe they can make greater and quicker wealth by foreign trade than by building up local industries. As a result, Niger Delta is faced only with one viable firm - the oil industry where almost every youth wants to be employed. The issue of only one viable and prosperous firm in the Niger Delta has given rise to a situation where plenty of money is chasing too few goods, namely inflation because, every youth cannot be employed in the oil industry, couple with a worsened inflation by our poor distribution system and the unpatriotic act of hoarders in our midst, unemployment abounds and the resultant effect is that youth restiveness becomes an order of the day in the Niger Delta region. 


\subsection{Misplacement of Societal Values}

In Niger Delta today, secularism has overtaken the place of societal values. The region is today housing a crop of youths who would want societal values relegated to the limbo and background of our social system, the dignity and amount of wealth have been substituted by some of these youths for the dignity and quality of human person. For some Niger Delta youths today, it is no longer your personality, quality and virtues that count, it is the volume of wealth, no matter how dishonest and unjust is your wealth and the means of livelihood. Ostentatious life-style, lack of fear of God is fast displacing the wisdom, the mobility and majesty of simplicity, and modesty. As more emphasis is laid on the material and on quantity, the quality and meaning of life suffer setbacks. Hence, the emergence and reign of youth mediocrity. These hoodlums are known by various names under the guise of Niger Delta freedom fighters. Thus, militarization, misuse of fire arms and dynamite, bombing of economic structures in strategic places, robbery, raping and kidnapping of foreigners and indigenes become an order of the day in the name of fighting for the socio-political liberation and economic emancipation of the Niger Delta people. The origin and evolution of the so called Niger Delta Freedom Fighters today is therefore traceable to three phases. The eras of Niger Delta freedom fighters, political monsters and hoodlums (James 2012: p. 36).

First there was a genuine struggle for socio-political liberation and economic emancipation of the Niger Delta people. This group was made up of intellectuals, human rights activists, civil right campaigners etc. with good intentions for the people of the region. Secondly, there is the group which I choose to call here political monsters because of their clandestine activities which is a public opprobrium in the Niger Delta political history.

Thirdly, these are the so called freedom fighters made up of hoodlums. They are tools in the hands of the second group. If Nigerian daily news papers are to be believed, the daily papers are well inundated with substantial evidences to prove that many arms have been received by this third group from the second group for the purpose of quest for political powers. The second and third groups constituted the socio-economic vandals of the region in the name of Niger Delta Freedom fighters and are responsible for some unnecessary youth restiveness arising thereof (Fred, 2010: p. 50).

\section{The Genuine Struggle}

\subsection{Marginalization}

The core Niger Delta was part of Eastern Nigeria which came into being in 1951. In 1953, Prof. Eyo Ita the premier of the Eastern region was expelled from office by the majority group in the region, the Ibos, This negative outlook and other trends signaled the political domination of the minorities by the majority groups. The minority groups were the Tivs, Nupes in the north, the Edos, Itsekiris in the west, the Ogbas, Ogonis, Ijaws in the east (Reed, 2006: p. 108). These have led to bloody clashes all over the region. Even today, large numbers of the minority such as the Ogbas, Itsekiris, Ikwerre and Ogonis are not satisfied with the issue of marginalization which is still going on in Nigeria today. We can recall in the past of many Niger Deltans who were in the vanguard of the genuine struggle they include Prof. Claude Ake, Ken Sarowiwa, Isaac Adaka Boro etc.

\subsection{Oil Revenue}

Derivation phenomena became questionable in Nigeria. When Niger Delta was seen as the dominant economic and treasure base of Nigeria. When coal of Ibos, cocoa of the Yorubas, cotton of the Hausa contributed most to the national budget, derivation was religiously adhered to. Chief Obafemi Awolowo in support of the then sharing formula has this to say:

Where the opponents of the principle (of derivation) believe that they have the advantages of numbers, they insist on all the revenues being collected into a common pool and then shared out on the basis of population. Where this advantage is absent, they still insist on a common purse from being made on the basis of equality. In a capitalist society, whether it is a federation or not, it is untenable and dishonest in the extreme to insist on sharing another state's wealth on any basis other than that which the rules of the capitalist game allow. In this kind of society, every state is perfectly entitled to keep any wealth that accrues to it either by the sweat of its brow, by cunning or by unaided bounty of nature. And to accuse a rich state of lack of fellow feeling or patriotism because it insist on keeping practically all that comes to it by whatsoever means is 
reasonable and unrealistic (Amanyie, 2006: p. 7).

In $1950,100 \%$ was the derivation formula in Nigeria. In 1960 it was reduced to $50 \%$, to $20 \%$ in 1975 , today it has depreciated to $13 \%$. It is pertinent to note that the politics of revenue allocation constitute a major threat to Niger Delta region. The region does not benefit in commensurate to the revenue accruing from her natural resources, rather the region is under developed and in abject poverty. Ogba Egbema Ndoni Local Government (ONELGA), Rivers state, the highest oil and gas producers in Nigeria is a case in point.

In the same vain a scholar observed

Oil and gas companies operating in the Niger Delta region should be compelled to comply with international environmental best practices, to ensure the protection of the natural habitats. They should be held responsible for any negative impacts of all their operations in the Niger Delta Region (Obaro, 2012).

Therefore, the issue of marginalization of Niger Delta region, cheating, selfishness and economic parasite of unproductive states, inadequate derivation formula, irrational politicking of the region's natural resources has among other social factors given rise to genuine Niger Delta struggle, leading to an unbeatable and incessant youth restiveness in different parts of Niger Delta.

\section{Ogba Theocracy: A Panacea to Niger Delta Youth Restiveness}

In the second part of this discussion, I suggest that Ogba theocracy a principled government which has an embodiment of religion and cultural ideology is the answer to Niger Delta youth restiveness. It is pertinent to note that no one state or region such as Niger Delta or Ogbaland could be deluded to allow the control or monopolization of her resources longer than necessary, as this could result into clashes. Other reasons for proffering Ogba theocracy or traditional government as a panacea to the causative factors of Niger Delta youth restiveness are as follows.

\section{Political Leadership}

Ogba theocracy is an embodiment of impersonal and good leadership. Hence, the culture maintained: As a leader, be it in the government, ministry or private sector or personal life, it is important to lead by personal examples. We must humble ourselves before our subjects. It is only by so doing that we would be able to communicate and understand their problems. A leader should always and at all times put on an impersonal character. The needs of the subject should be considered first. A true Ogbaman will not be at peace until his subjects are at peace. Our rest, peace and happiness are dependent on that of those around us. Starving your subjects, the youths, neighbours, the proletariat or the so called commoners because you are privileged to be in a leadership position is unculturally Ogba and negates Ogba philosophy of impersonal leadership. The socio-economic set up in the Niger Delta today whereby a government officer bathes himself with millions of Naira, while the subjects suffer in penury is a deviation of Ogba socioeconomic culture.

True to Ogba's culture, a hunter or fisherman who kills a big animal or plenty of fishes would not eat alone, he would ensure it goes round as much as he could share it. Fellow Niger Deltans, if we can enthrone this culture in this country, particularly Niger Delta, I am confident that Niger Delta youth restiveness arising from insensitive political leadership will be reduced to the barest minimum.

\section{Economic Situation}

Equally of note in the Ogba culture is sincerity of a leader to his oath of office and this enhances his sincerity to the people. Thus, an Ogba person before the assumption of exalted traditional office in the community may be given an oath of office which he must keep faithfully, punishable by the divinity when the oath of office is been defiled.

Although, it is true that Niger Delta political leaders had always taken the oath of office before the assumption of duty, it has become so ineffectual in the sense that the same leader who was empowered by an oath of office vide the constitutional laws of Nigeria, always turn back to challenge the public through the same enabling law over his misdeeds. It is a corresponding case of a scientific law, which provided a mechanical device for protection, only for the same science to provide another law which destroys the protective shield-what a double edged sword. Many political leaders of the Niger Delta who were caught by EFCC over financial misappropriations of 
huge sums of money have challenged EFCC through the same constitutions that brought them to office. What this connotes is that we can no longer continue with the practice of a double edged obnoxious system in the Niger Delta. Ogba cultural oath of office has been workable and has subsisted since ancient times till contemporary period. It is therefore a proffered panacea to youth restiveness in the Niger Delta in the sense that economic and financial impropriety which is one of the causative factors to youth restiveness would be minimized. Monies meant for youths' resourcefulness, empowerment and creativity will not be carted away by office holder without fear.

\section{Oil Industry}

The point being made here is that Ogba culture of self reliance, independent is a panacea to the youth restiveness emanating from the mentality in which almost all the youths want to be employed by the oil company. An Ogbaman is resourceful, full of initiatives, committed to a positive goal, daring, adventurous and hardworking. At a matured age, an Ogba person is not expected to be dependent on his parents, no matter how wealthy the parents may be. Any act of parasital existence is frowned at and unacceptable.

The spirit of self reliance and independence upon parents in Ogba culture was exemplified by Christ at the age of twelve years when he decided to leave his parents for the temple. As a youth, the tempo of his self reliance and his cosmological view of life in the King Solomon's temple is worthy of emulation. The desire for self reliance, self achievement and vocational independent of the youth is very intrinsic in Ogba culture and they leave no stone unturned to exploit it. Therefore, since the government cannot provide varieties of avenues for youth empowerment, self creativity, self reliance, resourcefulness and occupational independent, would it not be appropriate to recommend Ogba culture of self reliance and independent to the youth as a solution to avoid youth restiveness in the Niger Delta emanating from the desire of every youth seeking to be employed in the oil company? I express the greatest optimism to recommend Ogba consciousness of self reliance, independent to the youths of Niger Delta as a panacea to the problems in discourse.

\section{Misplacement of Societal Values}

Traditionally, Ogba theocratic culture laid more emphasis on the spiritual and social dimensions of human nature and value. The culture set very high value on religiosity, the sanctity and dignity of human life, social justice, honesty, truthfulness, simplicity and frugality, consideration for others, respect for social norms and sanctions. These societal values were veritable tools for moulding the characters of the youth for a better society. For Smart there is no gainsaying about this hence he wrote:

There is no doubt that religions have been influential in moulding the ethical attitudes of the society they are part of. Ironically, however, quite a number of those who profess these faiths either deliberately or ignorantly flout these moral prescriptions of their religions and hence, the social decay we found ourselves today (John, 2009: p. 206).

In the given circumstance, we therefore recommend Ogba theocratic government in the Niger Delta, where Ogba traditional religion and cultures would remould our youths for a better society.

Equally of note is the Ogba cultural spirit of service and love which was demonstrated by Christ and documented in the Holy Scripture. Christ consciousness was an embodiment and a continuum of Ogba cultural consciousness. In the spirit of Ogba culture of love and selfless service, Christ relieved the need of others. Ogba religious consciousness therefore connotes self sacrifice for the welfare of all. In reality, it means good works for the betterment of others. It requires personal sacrifice, self renunciation for the amelioration of others. Thus an Ogba conscious freedom fighter will not use fire arms to eliminate the people he is fighting for, he will not destroy their economic structures, he will not kidnap them, he will not abduct nor rape their children, he will not constitute himself a nuisance and an obstacle to peace and harmony in the society. His sole intention is triple to make the people live in peace, health and happiness in the community.

\section{The Genuine Struggle}

In Ogba theocracy to rob Peter to pay Paul is uncultural. An Ogba man does not reap where he did not sow. A situation by which in the government of Nigeria today, the hen that lays the golden egg; the oil producing com- 
munities are being marginalized, where derivation formula has become so twisted, inadequate and incommensurate to the revenue derived from the land is unculturally Ogba. In his Ali-Ogba. Ellah recalls historically the derivation formula of Ogbaland:

When Ogbas eventually settled down in Ogba Land, they established a political structure marked by "King and cabinet" the traditional cabinet posts reflect political offices, titles, rights, and privileges acquired by different Onuobdos (Ellah, 1986: p. 460).

Different (Onuobdos) quarters, persons were awarded positions based on hard work. To this end, Ellah elaborates that the Obosi people earned the title Ojoka defence minister of Ogbaland by merit. In like manner, other relative titles were awarded to deserving quarters of the land. Hence it is obvious that derivation formula of Ogba theocracy were each is paid according to production is the best and devoid of cheating.

\section{Conclusion}

Ogba theocracy is a form of government in which her principal organs are animated by religious values. Ogba theocratic government is headed by the Oba. In governance the Ogba theocracy incorporates the divine Laws of the Supreme Being, the ancestors and the deities. Socio-ethical values, such as honesty, non embezzlement of public funds, professionalism, respect for elders, selfless service etc dominates Ogba theocracy. In this wise researcher is of the view that such a refined contemporary system should be enthroned or acculturated by various governments in the Niger Delta as a panacea to many societal ills found in the region more especially youth restiveness which have become endemic in many sub Sahara Africa including the Niger Delta which we cite as a case point. Ogba theocracy will fight against marginalization, cult of gangsters; it will give appointments and resource control autonomy to deserving individuals, communities and states thereby minimizing youth restiveness in the Niger Delta.

Adamic sins which are still extant in our society today are problematic and devoid of positive knowledge for furthers civilization, they are represented in this paper as "restiveness" which manifest in the society as greed, adultery, fornication, political crisis, economic embezzlement, indiscipline, unlawful use of war weapons (AK 47, atomic bombs, dynamite etc.), assassinations, insincerity, misappropriations, unaccountability, inflation, marginalization, illogistic and harmful discoveries or inventions etc.

\section{References}

Amanyie, V. B. (2006). The Struggle of the Niger Delta, Nigeria. Owerri: Spring Field Publishers.

Ellah, J. F. (1989). Ali Ogba: The History of Ogba People. Enugu: 4th Dimension Publishers.

James, I. (2012). Religion and Change (p. 36). Lagos: Dimson Publishers.

John, S. (2009). The Politics and Religious Culture of a Nation. London: Oxford University Press.

Obaro, I. (2012). Discourse on the Niger Delta: Yesterday, Today and Tomorrow. (In Wilberforce Island Journal of History)

NDU: Department of History/Diplomacy.

Ordu, E. (2011). The Politics of Change in Nigerian Government. Abuja: Ivy Publishers. 